\title{
Penulisan Artikel Ilmiah bagi Guru Penjasorkes di Sekolah Dasar
}

\author{
Marsiyem $^{* 1}$, Silvi Aryanti ${ }^{2}$, Destriana $^{3}$, Destriani $^{4}$ \\ Pendidikan Jasmani dan Kesehatan FKIP Universitas Sriwijaya \\ Email: marsiyem53@yahoo.com, silviaryanti@fkip.unsri.ac.id, \\ destriana011289@yahoo.com, destriani12@gmail.com
}

\begin{abstract}
Abstrak
Pengembangan profesi guru khususnya guru Penjasorkes dilakukan dalam beberapa kegiatan, salah satunya melalui Artikel Ilmiah Olahraga. Kepmenpan No. 84/1993 tentang Jabatan fungsional guru dan angka kredit, bertujuan untuk membina karir kepangkatan dan profesionalisme guru, dan kebijakan itu mewajibkan guru melakukan ke-4 kegiatan yang menjadi bidang tugasnya seperti kegiatan bidang (1) pendidikan, (2) proses pembelajaran, (3) pengembangan profesi, dan (4) penunjang proses pembelajaran, dan hanya bagi guru-guru yang berhasil melakukan kegiatan dengan baik diberikan angka kredit. Kenaikan pangkat/golongan guru pembina IV/a ke atas mewajibkan adanya angka kredit dari kegiatan pengembangan profesi. Kemampuan menulis bagi guru merupakan tuntutan profesi yang harus dilakukan dan menjadi sarana bagi pengembangan diri dan syarat pengembangan karir seorang guru. Guru wajib memenuhi syarat berupa penulisan karya ilmiah yaitu menulis artikel. Syarat ini menjadi penghambat bagi guru dikarenakan rendahnya kemampuan dan minat menulis. Pelatihan ini bertujuan untuk mengetahui kemampuan guru penjasorkes dalam penulisan artikel ilmiah. Subjek dalam pelatihan ini yaitu guru Penjasorkes se kecamatan Sekayu. Hasil pelatihan adalah guru dapat membuat artikel ilmiah dengan mengacu pedoman penulisan tentang identifikasi, memilih dan merumuskan topik, menyusun kerangka tulisan, mengumpulkan bahan tulisan, menulis, menyunting, dan membuat artikel ilmiah. Pelatihan penulisan artikel ilmiah berdampak positif terhadap pengetahuan dan pengembangan diri.
\end{abstract}

Kata Kunci: Penulisan Artikel Ilmiah, Guru Penjasorkes, Kecamatan Musi Banyuasin

\section{Abstract}

Teacher professional development especially physical education and health teachers is carried out in several activities, one of which is through Sports Scientific Articles. Kepmenpan No. 84/1993 concerning teacher functional positions and credit numbers, aimed at fostering the career of the rank and professionalism of teachers, and the policy requires teachers to carry out the 4 activities which are their task areas such as activities in (1) education, (2) learning processes, (3 ) professional development, and (4) supporting the learning process, and only for teachers who successfully carry out activities are given credit numbers. Promotion / class of instructor teachers $I V / a$ and above requires credit numbers from professional development activities. The ability to write for teachers is a profession that needs to be done and becomes a means for self-development and the terms of a teacher's career development. Teachers must fulfill the requirements in the form of scientific writing, namely writing articles. This requirement is a barrier for teachers because of their low ability and interest in writing. This training aims to determine the ability of physical education teachers in scientific article writing. The subjects in this training were Penjasorkes teachers in Sekayu sub-district. The results of the training are that the teacher can make scientific articles by referring to writing guidelines about identifying, selecting and formulating topics, compiling writing frameworks, collecting written material, writing, editing, and making scientific articles. Training on scientific article writing has a positive impact on knowledge and selfdevelopment.

Keywords: Scientific Article Writing, Penjasorkes Teacher, Musi Banyuasin District 


\section{PENDAHULUAN}

Undang-undang

Republik

Indonesia Nomor 20 Tahun 2003 mengisyaratkan bhawa sistem pendidikan nasional adalah keseluruhan komponen pendidikan yang saling terkait secara terpadu untuk mencapai tujuan pendidikan nasional. Pendidikan yang bermutu tersebut sangat dipengaruhi oleh penyelenggaraan pendidikannya.

Guru-guru akan lebih mampu bekerja sebagai tenaga profesional dalam melaksanakan tugas dan tanggung jawabnya sebagai pendidik, namun harapan itu belum menjadi kenyataan. Hal ini karena masih mengalami banyak hambatan untuk menjadi tenaga pendidikan yang profesional walaupun guru-guru tersebut telah mendapat tunjangan profesi. Hambatan itu seperti rendahnya motivasi untuk mengembangkan profesi dirinya sebagai guru dikarenakan kurangnya penyuluhan, pelatihan bidang pengembangan profesi guru, serta kurangnya informasi tentang mempublikasikan tulisan ilmiah tersebut. Ketentuan umum UU No. 14 Tahun 2005 Tentang Guru dan Dosen. Guru adalah pendidik profesional dengan tugas utama mendidik, mengajar, membimbing, mengarahkan, melatih, menilai, dan mengevaluasi peserta didik pada pendidikan anak usia dini jalur pendidikan formal, pendidikan dasar, dan pendidikan menengah.

Guru Profesional dituntut untuk memiliki kemampuan dalam berbagai aspek. Tidak hanya memiliki kompetensi dalam pembelajaran, tetapi dalam hal penulisan karya ilmiah menjadi keharusan. Pola Pembinaan Profesionalisme Guru melalui Penulisan Artikel Ilmiah harus ditingkatkan secara simultan dan berkesinambungan. Brotowidjoyo (2002) artikel ilmiah sebagai bagian dari karya ilmiah adalah karya ilmu pengetahuan menyajikan fakta umum dan ditulis sesuai dengan metodologi penulisan yang baik dan benar. Suyitno (2011) menyatakan bahwa artikel ilmiah adalah karya tulis yang dirancang untuk dimuat di jurnal atau buku kumpulan artikel, ditulis dengan tata cara ilmiah disesuaikan dengan konvensi ilmiah yang berlaku.

Pengembangan profesi guru khususnya guru Pendidikan jasmani, olahraga dan kesehatan dapat dilakukan dalam beberapa kegiatan, salah satunya melalui artikel Ilmiah Olahraga. Berdasarkan Kepmenpan No. 84/1993 tentang Jabatan fungsional guru dan angka kredit bertujuan untuk membina karier kepangkatan dan profesionalisme guru, dan kebijakan itu mewajibkan guru melakukan ke-4 kegiatan yang menjadi bidang tugasnya seperti kegiatan bidang (1) pendidikan, (2) proses pembelajaran, (3) pengembangan profesi, dan (4) penunjang proses pembelajaran, dan hanya bagi guru-guru yang berhasil melakukan kegiatan dengan baik diberikan angka kredit.

Kenaikan pangkat/golongan guru pembina IV/a ke atas mewajibkan adanya angka kredit dari kegiatan pengembangan profesi. Pengembangan profesi terdiri dari 5 (lima) macam kegiatan yaitu: (1) menyusun karya tulis ilmiah olahraga (bagi guru penjasorkes), (2) menemukan teknologi pembelajaran olahraga yang tepat guna, (3) membuat alat peraga pembelajaran olahraga, (4) menciptakan karya seni bidang olahraga, dan (5) mengikuti kegiatan pengembangan kurikulum Penjasorkes.

Program studi Pendidikan Jasmani dan Kesehatan FKIP UNSRI memiliki Jurnal Altius yang sering kali masih mengalami kekurangan dalam penyediaan artikel ilmiah bermutu terutama dari guru penjas. Keberadaan naskah/artikel ilmiah dari para guru pendidikan jasmani sangat jarang sekali tampil di terbitan Jurnal Altius. Jurnal Altius sendiri merupakan salah satu 
jurnal ilmiah yang mencoba untuk mendesiminasikan segala macam pemikiran dan penelitian tentang pendidikan jasmani. Naskah/artikel dari guru-guru penjasorkes sering kali diperoleh redaksi dari beberapa rekan dosen di Prodi Pendidikan Jasmani dan Kesehatan FKIP UNSRI yang hanya memiliki akses terbatas pada beberapa guru pendidikan jasmani tertentu. Hal ini, bias diakibatkan oleh kurangnya informasi para guru pendidikan jasmani itu sendiri terhadap Jurnal Altius dan sebaliknya Jurnal Altius sendiri yang kurang mensosialisasikan pada guru pendidikan jasmani. Guru yang dapat mengembangkan profesi dengan baik dan berhasil, akan menjadikan dirinya seorang pendidik yang profesional, sehingga dalam setiap tugasnya baik dikelas maupun dilingkungan luar kerja dia akan selalu dihormati dan dikagumi baik oleh peserta didik maupun masyarakat sekitarnya. Pengembangan profesi merupakan hal yang mutlak harus dilakukan oleh setiap guru penjasorkes.

\section{METODE}

Waktu pelaksanaan kegiatan pelatihan ini adalah tanggal 3 s.d. 10 Oktober 2018. Tempat pelaksanaan pengabdian masyarakat dilakukan di Sekolah Dasar Negeri 8 Sekayu. Peserta yang berpartisipasi dalam penulisan artikel ilmiah yaitu guru Pendidikan Jasmani, Olahraga, dan Kesehatan.

Metode kegiatan pelatihan penulisan karya tulis ilmiah olahraga bagi guru-guru penjasorkes di Kabupaten Musi Banyuasin, setelah diberi pelatihan kemudian guru dibimbing untuk menerapkan hasil pelatihan dalam rangka meningkatkan kemampuan guru-guru dalam kegiatan teknis penulisan artikel ilmiah olahraga. Ada pun tahapan pelatihan adalah sebagai berikut:

\section{Tahap Persiapan}

Tahap persiapan ini dilakukan survei, pemantapan dan penentuan lokasi dan sasaran, penyusunan bahan/materi pelatihan yang meliputi; makalah dan modul untuk kegiatan pelatihan penulisan karya ilmiah bagi guru-guru penjasorkes SD Negeri 8 Sekayu Kabupaten Musi Banyuasin.

2. Tahap Pelaksanaan Pelatihan

Tahap pelaksanaan pelatihan, pertemuan pertama; memberikan penjelasan tentang penulisan karya ilmiah, sesi pelatihan ini menitikberatkan pada pemberian penjelasan mengenai memotivasi guru-guru olahraga agar mau menulis dan membuat karya tulis ilmiah olah raga, pertemuan kedua; ini yang menititik beratkan kemampuan melaksanakan kegiatan tentang identifikasi, memilih merumuskan topik, pertemuan ketiga; menyusun kerangka tulisan, mengumpulkan bahan tulisan, menulis, menyunting dan membuat artikel ilmiah.

Metode pelaksanaan kegiatan di atas untuk tercapainya tujuan pelatihan, maka pelatihan ini akan dilaksanakan dengan beberapa cara atau metode antara lain sebagai berikut:

1. Metode Ceramah

Metode ceramah dipilih untuk memberikan penjelasan tentang karya tulis ilmiah olahraga, memotivasi guruguru olahraga agar mau membuat karya tulis ilmiah olahraga, cara menanamkan pemahaman guru-guru Penjasorkes tentang teknis penulisan karya ilmiah olahraga yang sangat penting dikuasai oleh peserta pelatihan.

2. Metode Tanya Jawab

Metode tanya jawab sangat penting bagi para peserta pelatihan, baik di saat menerima penjelasan tentang penulisan karya ilmiah olahraga dan saat mempraktekkannya metode ini memungkinkan guru-guru olahraga menggali pengetahuan sebanyak 
banyaknya tentang penulisan karya ilmiah olahraga dan juga pengalaman setelah praktek menulis karya ilmiah.

3. Metode Simulasi

Metode simulasi dipilih karena sangat penting diberikan kepada peserta pelatihan terutama untuk memberikan kesempatan mempraktekkan materi pelatihan yang diperoleh. Harapannya, peserta pelatihan akan benar-benar menguasai materi pelatihan yang diterima, mengetahui tingkat kemampuannya menerapkan kegiatan penulisan karya ilmiah olahraga secara teknis dan kemudian mengidentifikasi kesulitan-kesulitan (jika masih ada) untuk kemudian dipecahkan.

\section{HASIL DAN PEMBAHASAN Hasil}

Berdasarkan potensi masingmasing pihak terkait dalam kegiatan pelatihan ini, maka bentuk pendampingan dan kerjasama menghadirkan sinergisme yang amat strategis dan positif antara lembaga perguruan tinggi dengan guruguru penjasorkes yang akan mendapatkan pelatihan dari tenaga edukatif terlatih profesional perguruan tinggi untuk meningkatkan kompetensinya dalam penulisan artikel ilmiah sekolah dan wahana strategis untuk menyebarluaskan ilmu pengetahuan pendidikan dengan sasaran dan jangkauan yang lebih luas yaitu guru-guru penjasorkes di Sekolah Dasar Negeri 8 Kecamatan Sekayu.

Dosen dan mahasiswa tim pengabdian pada masyarakat berperan strategis dalam setiap kegiatan baik pada kegiatan penyuluhan atau penataran maupun pada kegiatan pelatihan penulisan karya ilmiah olahraga. Masingmasing anggota tim menjalankan tugas dan fungsi yang relevan dengan materimateri pelatihan dan dosen senantiasa selalu berdampingan dalam memberikan bantuan teknik penulisan karya tulis ilmiah. Dalam kegiatan pelatihan penulisan masing-masing anggota bertindak sebagai penceramah, pembimbing, dan pendamping atau pengarah dalam bantuan teknis penulisan artikelilmiah olahraga.

Kegiatan pelatihan penulisan artikel ilmiah olahraga bagi guru penjasorkes di SD Negeri 8 Sekayu sangat cocok diterapkan. Guru mampu mempraktekan menulis artikel ilmiah dan guru bersedia mensosialisasikan tentang penulisan artikel ilmiah kepada rekan sejawat. Hal ini dapat mengembangkan profesi gutu dengan baik yang dapat membantu untuk kenaikan pangkat.

\section{Pembahasan}

Evaluasi adalah suatu rencana penilaian terhadap aspek pelatihan seperti evaluasi proses dan evaluasi hasil. Evaluasi proses meliputi pencapaian tujuan pelatihan yang dilakukan dengan angket tanya jawab dan observasi, sedangkan evaluasi aspek penyelenggaraan pelatihan meliputi pemberian angket untuk melihat indikator keberhasilan dalam pelaksanaan pelatihan penulisan karya ilmiah olah raga melalui evaluasi selama proses pelatihan, dan evaluasi pasca pelatihan.

Evaluasi saat pelaksanaan pelatihan yaitu keterlibatan dan kemampuan peserta setiap tahap pelatihan. Pada tahap akhir guru dapat melakukan kegiatan tehnis penulisan artikel ilmiah olahraga, yaitu: (1) mengindentifikasi, memilih dan merumuskan topik dan judul, (2) menyusun kerangka tulisan, (3) mengumpulkan bahan tulisan, mengorganisasikan, dan mengonsep tulisan, (4) menulis ilmiah dan menyunting, sedangkan indikator keberhasilan selama proses pelatihan dengan memperhatikan beberapa hal seperti:

(1) Kemampuan guru-guru olah raga dalam pemahaman kegiatan tehnis penulisan karya ilmiah yaitu: 1) 
mengidentifikasi, memilih dan merumuskan topik dan judul; 2) menyusun kerangka tulisan; 3) mengumpulkan bahan-bahan tulisan, mengorganisasikan, dan mengonsep tulisan; 4) menulis ilmiah dan menyunting.

(2) Keterampilan guru olah raga dalam melaksanakan kegiatan tehnis penulisan karya ilmiah, yaitu: 1) mengidentifikasi, memilih dan merumuskan topik dan judul; 2) menyusun kerangka tulisan; 3) mengumpul bahan-bahan tulisan, mengorganisasikan, dan mengonsep tulisan; 4) menulis ilmiah dan menyunting.

(3) Jumlah guru yang mampu dengan baik dan secara terampil melakukan kegiatan tehnis perpustakaan sekolah.

(4) Indikator keberhasilan pelatihan ini adalah apabila: 1) lebih dari $90 \%$ peserta/ guru olah raga memahami kegiatan pelaksanaan pelatihan penulisan karya ilmiah; 2) lebih dari $75 \%$ peserta/guru olah raga mampu mempraktekkan yaitu penulisan artikelilmiah olahraga; 3) lebih dari $50 \%$ peserta/guru penjasorkes bersedia mensosialisasikan kemampuan menulis artikelilmiah.

Berdasarkan indikator keberhasilan diperoleh evaluasi yaitu kemampuan guru penjasorkes sudah memahami tentang teknik penulisan artikel ilmiah. Guru terampil dalam menulis artikel ilmiah walaupun menemukan kendala. $85 \%$ guru mampu mempraktekan menulis artikel ilmiah dan guru bersedia mensosialisasikan tentang penulisan artikel ilmiah kepada rekan sejawat.

Keberhasilan suatu kegiatan pengabdian pada masyarakat akan dievaluasi berdasarkan taraf penyelesaian materi pelatihan, dan Tim Pengabdian kepada Masyarakat akan melakukan evaluasi dengan mengamati dan memeriksa karya tulis yang dibuat guruguru saat pelatihan. Instrumen kriteria penilaian tingkat kebermanfaatan kegiatan pelatihan ini diungkap dengan instrumen yang telah disiapkan, seperti pada tabel 3 di bawah ini.

Berdasarkan hasil evaluasi pelatihan penulisan artikel ilmiah bagi guru penjasorkes di SD Negeri 8 Sekayu dapet diperoleh yaitu guru memiliki pengetahuan tentang penulisan artikel ilmiah setelah diberikan materi. Adanya sesi tanya jawab tentang langkah-langkah menulis artikel ilmiah sehingga memecahkan masalah. Guru dibagi kelompok untuk berdiskusi tentang permasalahan yang ada untuk artikel ilmiah, kemudian tahap implementasi guru sudah dapat membuat artikel ilmiah dengan berpedoman pada langkahlangkah artikel ilmiah.

\section{KESIMPULAN}

Berdasarkan hasil dan pembahasan disimpulkan bahwa kegiatan pelatihan penulisan artikel ilmiah olahraga bagi guru penjasorkes di SD Negeri 8 Sekayu sangat cocok diterapkan. Guru mampu mempraktekan menulis artikel ilmiah dan Guru bersedia mensosialisasikan tentang penulisan artikel ilmiah kepada rekan sejawat. Hal ini dapat mengembangkan profesi gutu dengan baik yang dapat membantu untuk kenaikan pangkat.

\section{DAFTAR PUSTAKA}

Brotowidjoyo, M. D. (2002). Penulisan Karangan Ilmiah. Jakarta: Akademika Pressindo.

Departemen Pendidikan Nasional. (2003). Undang-Undang Nomor 20 Tahun 2003 Tentang Sistem Pendidikan Nasional. Jakarta: Depdiknas.

Suyitno, I. (2011). Karya Tulis Ilmiah (KTI), Panduan, Teori, Perlatihan, dan Contoh. Bandung: Refika Aditama. 
Undang-Undang Nomor 14 Tahun 2005

Tentang Guru dan Dosen. Jakarta.

PT Media Pustaka Mandiri. 